\title{
COVID -19 Emergency Laws and Law Enforcement in Nigeria America And Britain.
}

\author{
*Monday. O. Oseghale Esq. LL.M, Ph.D., BL. \\ Senior Lecturer, Department of Public Law, Faculty of Law, Ambrose Alli University, Ekpoma, Edo State, \\ Nigeria.
}

\begin{abstract}
*
In Nigeria, the Covid-19 pandemic is showing two worst features of Nigeria's attitude towards law. These are its flagrant utter disregard for rule of law and its flagrant abuse of human Rights. All over the world, it is quite obvious that there is absolute indisputable need for lockdowns and social distancing to stop the spread of Corona virus Pandemic. That is scientifically and medically established. However, both measures must conform with the two conditions of rule of Law and Human Rights. In an attempt to contain the spread the governments resort to emergency laws which violate the human rights of the citizenry. The thrust of this paper is to examine emergency laws during Covid-19 and enforcement of emergency laws in three different climes; Nigeria, America and Britain, and how these emergency laws have been enforced in violation of the fundamental rights of the people with the resultant human rights abuses. The paper finds that in enforcing emergency laws to contain this pandemic, the rights of the citizens are hampered and abused. In Nigeria the Quarantine Act of 1926, does not confer powers to violate the human rights and personal liberty of Nigerians. Also in America and Britain where such laws exist to contain the pandemic, the laws are to be enforced with regards to the rights of the people. It therefore concludes that in an attempt to contain the spread of such pandemic, through lockdowns and social distancing, it must be done within the parameters of the rule of law and protection of the rights of the citizens and the enforcement must be on the principle of proportionality. It recommends that if the government wants such powers, it should declare a state of emergency or enact a primary legislation that sets out such specific powers and not merely on Executive order.
\end{abstract}

Keywords: Covid-19, Emergency, Emergency laws, State of Emergency and Law Enforcement.

DOI: $10.7176 / \mathrm{JLPG} / 99-13$

Publication date:July $31^{\text {st }} 2020$

\section{Introduction:}

In Nigeria, America and Britain, the governments have enacted emergency measures in order to combat the spread of C0VID-19. Depending on the statutory powers used to implement these emergency measures, as governments have various enforcement powers available to them, without necessarily infringing on the rights of the citizens. Public health orders that are subject to these new enforcement measures including those requiring mandatory self -isolation, restrictions on gatherings of more than 20 persons and required closures of nonessential businesses. However, in enforcement of these actions, the police and other security agencies cannot interfere with individual liberty more than is reasonably required. The aim of this paper in the light of the above is to examine emergency laws and law enforcement in the midst of COVID-19 with their attendant effects on the rights of the citizens. The paper further seeks to examine governments' response to COVID-19 with the enactment of emergency powers, the sight of uniformed Military and Police on the roads, also in enforcement of curfews, lock downs and social distancing. The paper, finds that measures taken to enforce the emergency laws have relegated certain rights which resulted in acts which are not proportionate and limited to those strictly required by the exigency of the situation. It recommends that such enforcement must be statutorily conferred by legislation. And such measures must be proportionately and sensibly enforced.

\section{Clarification of Terms}

Some terms in this paper need clarification, these are; Covid-19, Emergency, Emergency Laws, State of Emergency, and Law Enforcement.

\section{Covid-19}

Covid-19 is a disease caused by a new strain of Corona virus. "Co" stands for Corona, "V" for Virus and "D" Disease. Formerly, this disease was referred to as "2019" novel Corona virus or "2019-Cov".

According to Webster Dictionary ${ }^{1}$ it is a mild to severe respiratory illness that is caused by a Corona virus (fever acute respiratory syndrome Corona virus 2 of the genus Beta corona virus), is transmitted chiefly by contact with infections materials (such as respiratory droplets) or with objects or surfaces contaminated by the

${ }^{1}$ www.merriam-webster.com last accessed on 16/6/2020 
causative Virus and is characterized by fever, cough and shortness of breath and may progress to pneumonia and respiratory failure.

Covid-19 is the name of the disease caused by a SAR-COV2 Virus. In its full form Corona virus disease of $2019^{1}$. Covid-19 was given by the WHO on February 11, 2020 for the disease caused by the novel Corona virus SAR-COV2. It started in Wuhan, China in late 2019 and has since spread worldwide.

\section{Emergency}

In law, emergency refers to an event or situation that threatens or damages to human welfare, only if it involves, causes or may cause loss of human life, human illness or injury, homelessness, damage to property, disruption of a supply of money, food, water, energy or fuel, disruption of a system of communication, disruption of facilities for transport or disruption of services relating to health ${ }^{2}$.

It also means, a sudden unforeseen happening which requires action to correct or to protect lives and property $^{3}$. Therefore, emergency as it relates to Covid-19 is an unforeseen happening which requires immediate action to protect lives and property from being destroyed or damaged.

\section{State of Emergency}

State of Emergency is a situation of national danger or disaster in which a government suspends normal constitutional procedures in order to regain procedure ${ }^{4}$. It also means "when a government gives itself special powers in order to try to control an unusually difficult or dangerous situation, especially when this involves limiting people's freedom"s.

Article 4 of the International Covenant on Civil and Political Rights states that;

In time of emergency which threatens the life of the nation and the existence of which is officially proclaimed, the states parties to the covenant may take measures derogating from their obligations under the present covenant to the extent strictly required by the existence of the situation, provided that such measures are not inconsistent with their other obligation under international law and do not involve discrimination solely on the ground of race, color, sex, language ,religion or social origin ${ }^{6}$.

From the above definitions, is clear that there is a difference between "normal time" and a "state of emergency". In normal times, the powers of government in respect of security are strictly limited by the constitution and the laws of the nation. While emergency exists, where "any action has been taken or is immediately threatened.... Of such a nature and on so extensive a scale....to deprive the community of the essentials of life" or where "circumstances exist, or are likely to come into existence, whereby the public safety or public order is or is likely to be imperiled"7.

A state of emergency, is a situation in which a government is empowered to perform actions or imposes policies that it would normally not be permitted to undertake. A government can declare such a state during a natural disaster, civil unrest, armed conflict, medical pandemic or epidemic or other bio security risk. Such declaration alerts citizens to change their normal behavior and orders. Government agencies to implement emergency plans ${ }^{8}$.

\section{Emergency Law}

Emergency Laws category includes all legislation referring to the state of emergency in all its forms and suspension of the constitution on behalf of state security, including anti-terrorism legislation. The closest definition to emergency law is defined in "Emergency Act". It defines it as "an act to authorize the taking of

\footnotetext{
${ }^{1}$ https:www.goodrx.com. last accessed 16/6/2020

${ }^{2}$ https://legal.dictionary.thefreedictionary.com. Last accessed on 02/06/2020.

${ }^{3}$ Ibid.

${ }^{4}$ Available at http://oxforddictionaries.com/definition/english/state $\% 2$ bof $\% 2$ emergency/. Accessed 16/6/2020

${ }^{5}$ Longman Online Dictionary. available at http://www.idoceonline.com/dictionary/statesof emergency last accessed on $19 / 6 / 2020$.

${ }^{6}$ International Covenant on Civil and Political Rights (adopted 16 December 1966, entered into force 23 ${ }^{\text {rd }}$ march 1976) 999 UNTS (ICCPR).

${ }^{7}$ Stanley Yeo Meng Heong, "Legislative Control of Emergency Powers in New Zealand and Britain: An Appraisal (1984) 5 sing.L.Rev.112.

${ }^{8}$ See https://enrm,wilipedia. Org. accessed on 16/6/2020.
} 
special temporary measure to ensure safety and security during national emergencies and to amend other acts in consequence thereof ${ }^{1}$.

For a proper understanding of the direction of the title of this paper, in $1988^{2}$, Emergencies Act was passed in Canada. In the Act, "National Emergency" which is a situation of national emergency means;

For the purpose this Act, a national emergency is an urgent and critical situation of a temporary nature that'

(a) Seriously endangers the lives, health or safety of Canadians and is of such proportions or nature as to exceed the capacity or authority of a province to deal with it, or....

\section{Law Enforcement}

Law enforcement is an umbrella term for the activities of some members of government who act in an organized manner to enforce the law by discovering, deterring, rehabilitating, or punishing people who violate the rules and norms governing that society ${ }^{3}$. The above only describes what law enforcement is and does not define it. However, the description has given an insight to the direction of this paper.

\section{Agencies Responsible for Law Enforcement.}

Most law enforcement is conducted by some types of law enforcement agency, with the most typical agency fulfilling this role being the police. Social investment in enforcement through such organizations can be massive, both in terms of the resources invested in the activity, and in the number of people professionally engaged to perform those functions ${ }^{4}$.

Law enforcement is a subsystem of society that promotes adherence to the law by discovering and punishing persons who violate rules and norms governing that society. Law enforcement agency is an agency responsible for enforcement of laws. In some jurisdictions or climes, such organization is called police services. While in other climes they are called sheriff's office /department, investigative police service, bureau. These are FBI, USMS, ICE, CBP, ATD, DEA, USSS ${ }^{5}$. In other climes like America, the agencies responsible for law enforcement is the police. Under it, you have other agencies responsible for the enforcement of laws, in those agencies, the department that enforces the law is still the police; for examples; the following agencies;

1. Federal police

2. Military police

3. Police department

4. Private police

5. Secret police

6. State police

From the above, even in other agencies, it is the police department or unit or section that is still responsible for the enforcement of law. In Nigeria and Britain, the police is also responsible for the enforcement of law.

\section{Law Enforcement Agents in Nigeria}

The Origin of the Nigeria Police Force dates back to 1861. The force was regarded as Hausa Constabulary, which its primary duty was to protect the trade interest of the Royal Company along the River Niger in the North. This special Constabulary metamphosis into Nigeria Police Force.

Under the 1999 Constitution, the Nigeria Police Force was established. It occupies a very important position in the maintenance of internal security in democratic society, hence they are given powers by an

\footnotetext{
${ }^{1}$ This definition is found in "Justice Laws Website" in S//laws.lois.justice.gc.ca. last accessed on 16/6/2020.

${ }^{2}$ See section 3 of the Emergencies Act, 1988. This Act was assented to on the $21^{\text {st }}$ July, 1988. In its preamble, it is stated that the "Governor in Council, in taking such temporary measures, would be subject to the Canadian Charter of Rights and Freedoms and the Canadian Bill of Rights and must have regard to the International Covenant on Civil and Political Rights, particularly with respects to fundamental rights that are not to be limited or abridged even in a national emergency".

${ }^{3} \mathrm{https} / / \mathrm{en}$.m.wikipedia.org. last accessed on 16/6/2020. Law enforcement is a term which encompasses police, courts and corrections, it is most frequently applied to those who directly engage in patrols or surveillance to dissuade and discover criminal activity, and those who investigate crimes and apprehend offenders. A task typically carried out by police, sheriff or another law enforcement organization.

${ }^{4}$ Karem M. Hess, Christine Hess Orthman, "Introduction to Law Enforcement and Criminal Justice (2008) p.1.

${ }^{5}$ hyttp://disoveringpolcing.org/whats-like/?fa=types-jobs. Outside North America such organizations are called police services. In North America, some of these services are called police. While some have other names. See section 4 of the Police Act, Cap. P19.L.F.N.2004.
} 
enabling statute to discharge their task and bring society to order to avoid anarchy and hardship. Section 4 of the Police Act $^{1}$ states the primary duty of the Nigeria Police. This include;

Prevention and detection of crime the apprehension of offenders preservation of law and order protection of life and property. The enforcement of all law Regulation within which they are directly charge. Military duties within and outside Nigeria it may require by the law

In Nigeria, agencies responsible for enforcement of laws are the following;

1. Federal Road Safety Corps

2. National Agency for the prohibition of Trafficking in persons

3. Nigeria Police Force

4. Department of State security service.

The Nigeria Police Force is the principal law enforcement and the lead security agency in Nigeria ${ }^{2}$. The Nigeria Police Force is a very large organization consisting of 36 state commands. The agency is currently headed by IGP. Adamu Muhammed.

\section{Law Enforcement Agents in America}

Law Enforcement officials play an important role in America Communities. They undertake efforts to ensure justice for the approximately 8.25 million criminal offences each. They also in an effort to ensure public safety and hold individuals accountable for violating the law ${ }^{3}$.

The purpose of law enforcement in a free society is to promote public safety and uphold the rule of law so that individual liberty may flourish. In the early $1800 \mathrm{~s}$, the founder of Modern Policing, Sir Robert Peel, is believed to have said; "the police are the public and the public are the police 4 . This statement reflects the dual role that members of law enforcement hold in our society. Police officers are both part of the community they serve and the government protecting that community. Proper policing practices require that law enforcement build positive relationships with their community, respect Civil Liberties and avoid tactics that encourage the use of excessive force against citizens.

Law enforcement agencies respond to, detect and prevent crime with this perspective, it is recognized that police officers play a significant role in adapting and responding to unexpected or unknown situation as well as recognized situations such as theft or domestic dispute.

The primary role of the police is to enforce the law. The first contact victims have with the police usually happens when they call for help or make a complaint. Complaints or calls for service usually result in an accident report. Police may interview victims any witnesses to see if there is enough evidence to lay a charge . $^{5}$

\section{Law Enforcement Agents}

In American law, enforcement officers are categorized into the following; Constable, Corrections, Detective, Marshal and Deputy Marshal, Private Investigator, Peace Officer, Police Officer, Park Ranger, Sheriff, Under Sheriff, and Duty Sheriff, Bounty Hunter, Special Agent, Trooper, Inspector etc.

\section{Law Enforcement Agents in Britain.}

Law enforcement in the UK is organized separately in each of the legal systems of the UK, England and Wales, Northern Ireland and Scotland ${ }^{6}$. Most law enforcement is carried out by police officers serving in regional police services (known as territorial police forces) within one of those jurisdictions. These regional services are complemented by UK- wide agencies, such as the National Crime Agency and the National Specialist Units of certain territorial police forces, such as the specialist operations directorate of the metropolitan police.

\footnotetext{
${ }^{1}$ Cap. 14 LFN 2004: see also the Role of Law Enforcement Agencies the promotion and sustainability of participatory democracy and Rule of law. A speech delivered by Mr. Sunday Ehindero (IGP) Ably Represented by CP Bukar Mams Commissioner of Police Kwara State Command on Wednesday 13 ${ }^{\text {th }}$ December, 2006. Retrieved Online at www.mafng.org. on $17 / 6 / 2020$.

${ }^{2}$ Nigeria/Africa/member countries/internet/home-INTERPOLInterpol.int. last accessed on 17/6/2020

${ }^{3}$ Jeremiah Mosteller, the Role of Police in America. Retrieved from V.CharlesKOChristute.org. Accessed online on 17/6/2020.

${ }^{4}$ Ibid.

${ }^{5}$ https://www.gov.mb.ca.pubs. Last accessed on 22/6/2020.

6 "Code of Conduct for Police Officers" North Torkshire Police Federation. Retrieved online https.//en/m/wilipedia.org. last accessed on 30/6/2020.
} 
Police officers are granted certain powers to enable them to execute their duties. Their primary duties are the protection of life and property, preservation of peace and prevention and detection of criminal offences. In the British Model of policing, officers exercise their powers to police with the implicit consent of the public. This is referred to as "policing by consent", the phrase used to describe this. It expresses that the legitimacy of policing in the eyes of the public is based upon a general consensus of support that follow from transparency about their power, their integrity in exercising those powers and their accountability for doing so ${ }^{1}$.

In the UK, every person has limited powers of arrest if they see a crime being committed at common law, in Scotland, and in England and Wales, if the crime is indictable ${ }^{2}$. These are called "every person powers commonly referred to as citizens arrest". In England and Wales, the vast majority of attested constables enjoy full powers of arrest and search as granted by the police and Criminal Evidence Act $1984^{3}$.

The purpose of the police is to uphold the law fairly and firmly to prevent crime, to pursue and bring to justice those who break the law, to keep the Queen's peace, to protect it, help and reassures the community and to be seen to do all this with integrity, common sense and sound judgment. The police must be courteous and patient acting without fear or favour or prejudice with the right of others and to apply force which is necessary to accomplish law duty ${ }^{4}$.

\section{Law Enforcement Agencies in Britain.}

There are a number of agencies that participate in law enforcement in the United Kingdom, which can be grouped into three general types;

\section{Territorial Police Forces}

This carries out the majority of policing. These are police force that cover a police area (a particular region) and have an independent police authority. Current police force have their grounding in the Police Act 1996 (in England and Wales), a combination of police (Scotland) Act 1967 and Police and Fire Reform (Scotland) Act 2012 (in Scotland) and the Police (Northern Ireland) Act 2000 (in Northern Ireland), which prescribed a number of issues such as appointment of Chief constable, jurisdiction and responsibilities ${ }^{5}$.

\section{National Law Enforcement Bodies}

This is the National Crime Agency and the national police forces that have a specific non- regional jurisdiction such as the British Transport Police. The serious organized crime and police Act 2005 refers to these as "Special Police Forces", not inducing the NCA which is not a police force. In addition, there are non -police law enforcement agencies, whose officers are not police officers, but still enforce laws and other bodies with sole investigatory powers ${ }^{6}$.

\section{Miscellaneous Police Forces}

These police forces generally come under the control of local authority, public trusts or even private companies. Examples, includes some ports and the Mersey Tunnel's Police. They could have been established by Individual Acts of parliament or under common law powers. Jurisdiction is generally limited to the relevant area of private property alone and in some cases (eg. Docks and Harbours) the surrounding area. This, together with the small size of the police forces, means they are often reliant on the territorial force for the area under whose jurisdiction they all assist with any serious matter ${ }^{7}$.

\footnotetext{
${ }^{1}$ Ibid. "policing by consent" UK Government House as at 10 December, 2012.

${ }^{2}$ Ibid. "Police and Criminal Evidence Act, 1984 (c.60)- statute law database. See statutelaw.gov.uk. retrieved on 30/6/2020.

${ }^{3}$ For the purposes of this legislation, "Constable is defined to mean all Police Officers that have wide- ranging powers, they are still subject to the same ranging powers. Laws as members of the public (aside from specific exemptions such as the carrying of fire arms and certain round Traffic legislation).

${ }^{4}$ See Law Enforcement Reference Mannal. The United Kingdom of Great Britain and Northern Ireland (UK) Retrieved online. The duties and functions of the police in Scotland are the same with other jurisdiction in Britain the main functions of the service can still be summarized in words of the Report of the 1962 Royal Commission. See the police (Scotland) Act 1967 (as subsequently amended) which laid down the general functions and jurisdictions of the police constables.

5 https://en.m.wikipedia.org last accessed on 17/6/2020. These forces provide the majority of policing services to the public of England and Wales. These forces are known as "Home Office Police forces" due to the central government department, the Home Office being responsible for and providing the majority of the funding these police forces.

${ }^{6}$ The National Law Enforcement bodies operate in more than one country of the UK. The remit of some of the force is further limited to the areas that they police, such as railway infrastructure. The Anti - terrorism, Crime and Security Act 2001 gave the British Transport Police and Ministry of Defence, Police a limited conditional authority to act outside of their primary jurisdiction, if the situation requires urgent police action and local force are not readily available or if they believe that there is risk to life or limb or where they are assisting the local force.

${ }^{7}$ Ibid.
} 


\section{Enforcement of Covid-19 Emergency Laws in Nigeria, America and Britain.}

\section{Nigeria}

The responses by various countries or governments to the Corona virus crisis have included a strict curtailment of the right to freedom of movement and curtailment to some other rights. There have been imposed emergency laws and further limitations as part of an officially declared state of emergency, those special measures made government to impose extra-ordinary legal measures.

The Corona virus Pandemic is applying two of Nigeria's attributes; its fragrant violation of human rights and its utter disregard for the rule of law. President Buhari of Nigeria once said that "Rule of law must be subject to the supremacy of the nation's security and national interest" ${ }^{1}$. The COVID-19 emergency has provided cover for the magnification of such power abuses. According to Olu Fasan, it is stated that;

"Covid-19 has given leaders around the world an excuse to violate human rights and the rule of law". As one Senior United Nations Official recently put it;"We could have a parallel epidemic of authoritarian and repressive measures following close to, if not on the heels of a health epidemic".

That's true Autocrats are becoming even more authocractic as they use Covid-19 as an excuse to introduce self -serving draconian measures.

However, in Nigeria, on the 29th March, 2020, President Buhari imposed a lockdown on Abuja, Lagos and Ogun States. He directed the "Cessation of all movements" and ordering "all citizens to stay in their homes", and "all businesses and offices to be fully closed". The question to ask at this junction is, whether the orders of $29^{\text {th }}$ March, 2020 were backed by legal authority or law. It is my humble opinion that the President address was at best valuable as advice but has not the slightest legal effect, without statutory authority. He later issued the Covid-19 Regulation 2020, using powers under the Quarantine Act 1926, a Colonial era law enacted to quarantine people and areas with infectious diseases. But while the Covid-19 Regulation gives some legal effect to the President's lockdown measures, it certainly does not give legal cover for the human rights violation by security operatives purporting to be enforcing the government's corona virus orders. Recently, the President urged security agencies "to deploy tact and caution in enforcing the rules". The question is, do they have the powers to violate people's human rights and personal liberty in the first place? The answer is capital NO. The reason is that, government can only restrict, infringe or suspend human rights either by declaring a state of emergency or introducing a specific federal statute or law, both of which require the approval of the National Assembly or State Assembly, pursuant to section 4 of the 1999 Constitution $^{2}$. It is submitted that the Quarantine Act 1926 nor the COVID-19 Regulation 2020 issued pursuant to that Act gives the wide-ranging powers it is now exercising to violate the human rights of Nigerians. As a result, solders and other security operatives are brutalizing Nigerians on the street ${ }^{3}$. Furthermore, another couple named Mrs. Funke Akindele Bello and her

\footnotetext{
${ }^{1}$ Olu Fasan, Nigeria's Covid-19 Lockdown must be Lawful and Sensibly Enforced. Published on $13^{\text {th }}$ April, 2020. Retrieved online on $30 / 6 / 2020$.

${ }^{2}$ Section 4 (2) of the Federal Republic of Nigeria Constitution, 1999.

${ }^{3}$ See the Punch Newspaper of April 3, 2020 accessed online on 1/6/2020 via; punching. Com-deli with caption; "Solders shoots Motorist Deed in Delta. It was represented that a Motorist identified as Joshua Pessu, was shot dead in Warri. Delta State, on Thursday by a solders for alledgiedy flouting the state government's sit at home order to prevent the spread of the corona virus. An eye witness account was that the said motorist was crushing in a black Toyota Camry car without plate number, failed to stop at a Military checkpoint on the NPA Road, when the Soldiers ordered him to stop. However, the Motorist was alleged to have accelerated the car in a bid, to beat the security personnel. But a solder in the security team, who was apparently infuriated by the Motorists effrontery fired at the right rear tyre of the car in order to force the driver to stop. The Motorist continued driving for several meters until he got to a location and abruptly parked the vehicle in the middle of the road. He jumped out of the car to escape, but a bullet from the gun of one of the Soldiers pursuing him, hit him. This was also reported by the Premuim Time Newspaper, April, 2, 2020 by Cletus Ukpong (Journalist). Also on the $10^{\text {th }}$ May, 2020, the Governor of Rivers State ordered the demolition of two hotels in Eleme L. G. A. outside of Obio/Akpor and Port Harcourt L. G. A. this was done pursuant to Executive order 6. The Executive Order was made pursuant to the Quarantine Act, in which a demolition order was not one of the punishments or sanction. The Governor was the complainant Prosecutor and Judge. There was no court order for such exercise, but flagrant impunity. The two hotels; which were demolished were; Alode Hotels in Eleme LGA, and Etemet Hotel in Onne. However, after the demolition, the owner of one of the Hotels, was charged to a Magistrate Court in Port Harcourt and he was convicted and fined $\$ 50,000$ for contravening the state Executive order on Covid-19. One of the Owners named Azoroh was ordered to be quarantined at the isolation centre in Yakubu Gowon Stadium, Elekahia for 14 days to ascertain his corona virus status. The conviction was made pursuant to paragraphs 3 of the Executive Order number 7.

The draconian Lockdown orders without proper authority, than overzealous security agencies enforce the orders by violating
} 
husband, JJC Skillz were on the $6^{\text {th }}$ of April, 2020 charged and convicted for violating the social distancing directives of the Governor of Lagos State. They were convicted based on want of social distancing in their residence. The question now is, Does the Quarantine Act, 1926, confer powers on the government to violate the human rights and personal liberty of Nigerians ${ }^{1}$. The answer is No. whether measure or laws that must be employed in enforcing the Lockdowns and Social distancing they must be enforced within the ambit of the laws pertaining to human rights.

\section{America}

In America, authorities have resorted to repressive and overreaching measures that unduly restrict human rights in the name of "protecting" people from Covid-19. It is even said that Evidence Lab and regional experts verification carried out, revealed that over the past seven weeks, there are 60 incidents of government using arbitrary, punitive and repressive tactic in enforcing Covid-19 measures ${ }^{2}$.

Many stay-at-home orders include language specifying that non- compliance will be enforced through civil or criminal penalties. Civil penalties can include times, orders to suspend business operations and or revocation of licenses. For example, Kansas City, Missouri's stay-at-home order, states that a violation of any of its provision constitutes an imminent threat, creates an immediate menance to Public Health and shall be considered a violation of section 50 -155 of the City's Code of Ordinance. This include; "fines, orders to suspend business operations and other penalties ${ }^{3}$.

Furthermore, in Indiana, Executive order to discontinue in person dining, which can result in "suspension or revocation of an alcoholic beverage permit ${ }^{4}$ was passed.

Criminal enforcement can result to arrest for a misdemeanor and a fine or possible imprisonment ${ }^{5}$. In other jurisdictions like San Francisco, police Department, it is stated that,

We are not interested in using a criminal justice approach for public health

challenge. This is about educating the public about voluntary compliance.

The Lockdown adopted by San Francisco is more civil and ending and is commendable.

The Lockdown in California in US, being the first state to issue order for citizens to avoid non-essential outdoor activities in mid-March, but major cities and potential hotspots have issued a stay at home order. Chicago, the third-most populated US city, issued an effective Lockdown as of Saturday, March $21^{\text {st }} 2020$ at 5pm, until further notice, while also closing all public facilities ${ }^{6}$.

However, the issue at this juncture is due to the pandemic, quarantine measures that have been put in place, across the globe, while restriction of movement of free people would fall under a human rights violations.

the human rights of Nigerians. For the order to be legitimate, the lockdown must be lawful and sensibly enforced.

${ }^{1}$ In this case, the Lagos State Government on 21/3/2020 banned all religious and social gatherings of over 20 people. Section 1(2) of the Lagos State Infectious Disease (Emergency Prevention) Regulation 2020. The Regulation Provides; "All Acts done prior to be commencement of these Regulation to curtail the spread of Coronavirus Disease 2019 (Covid-19) are hereby ratified". The pronouncement by the Governor on 21/3/2020 is an official proclamation that falls under one of the acts, done prior to the commencement of the Regulation. It is therefore taken to have been incorporated by reference into the Regulation. Consequently, the gathering of over 20 people stands expressly and specifically prohibited in Lagos State. This clearly meets the provision of section 36 (12) of the 1999 Constitution which states that a person shall only be convicted on an offence defined by law. The Regulation was made by the Governor in exercise of his power under existing laws such as the Quarantine Act and the Public Health Law of Lagos State and qualifies as a subsidiary legislation. Therefore, the Regulation has the force of law. However, it must be noted that the legislation was not passed into law by the Lagos State House of Assembly. We can safely conclude that the Regulation is not a law passed by the State House of Assembly, as a result, it violates the fundamental rights of the citizens. See https://www.pulse.ng.celebrities. Funke Akindele and her husband, JJC Skillz have both been sentenced to 14 days of community service with a fine of 100,000 by Chief Magistrate Yewanda Aje-Afunwa at Ogba Magistrate Court on Monday April 6, 2020.

${ }^{2}$ Amnesty International Report on Authorities must protect people from Covid-19 instead of resorting to repressive measures. It was found by Erika Guevara-Rosas, Americas Director at Amnesty International that the use of detention as a first rather than last resort, excessive and unnecessary use of force in the enforcement of Covid-19 lockdowns and imposition of mandatory quarantines in inhuman conditions. Available at www.amnesty.org. last accessed on 2/7/2020.

${ }^{3}$ See WWW.americaprogress.org. last accessed on 2/7/2020.

${ }^{4}$ Ibid.

${ }^{5}$ For instance, Mecklenburg Country, North Carolina's joint proclamation declares that any person who violates any of its prohibitions or restrictions shall be guilty of a class 2 misdemeanor. Meanwhile, Wisconsin's emergency order specifics that a "violation or obstruction of this order is punishable by up to 30 days imprisonment, or up to \$250 fine or both. See WWW.americanprogress.org. last accessed on 2/9/2020.

${ }^{6}$ See en.as.com issued on 7/4/2020 with the caption "Corona virus Lockdown in USA: which states and what measures have been applied? Last accessed on 2/7/2020. It is also stated that several states have already ordered businesses, schools and workplaces to close and enforce social distancing by limiting public gatherings, with California, Illinois, Indiana, Michigan, Ohio, Washington, West Virgnnia and Wisconsin adopting most compressive polices by mandatory state wide quarantine. 
This abusive policy is not new. The situation presented by the Covid-19 requires many countries worldwide to take extraordinary measures, protect the health and wellbeing of the population. Even in a public emergency, these steps need to be based on the rule of law. The WHO has stated that stay-at-home measure for slowing down the pandemic must not be done at the expense of human rights ${ }^{1}$. In America, especially in San Francisco, the law goes beyond enforcement, but education and enlightenment.

There are seven ways the Corona virus affects human rights $^{2}$. These are Early censorship, the right to health, Activists harassed and intimidated, Regional Crackdown on fake news, Discrimination and Xenophobia, Border Closure, etc.

\section{BRITAIN}

In Britain, the Prime Minister, Boris Johnson Ordered UK lockdown to be enforced by police ${ }^{3}$. This extended to ban on gatherings of more than twenty people and strict limits on exercise and that people would only be allowed outside to buy food or medication or to travel to work if absolutely necessary. All non-essential shops will close with immediate effect. It is worthy of note that the police had no legal powers to enforce the order because, the emergency legislation was not in place. He stated;

In the past few days, there had been concern about announcing a lockdown before police had the proper powers to enforce one. It will only come into law when the emergency Corona virus legislation is passed in the week $^{4}$.

In the UK, the government introduced new legislation in the Commercial context, but what then are the human rights implications. In the first place, on 9 March, 2020, parliament approved the Health Protection (Corona virus). Under these regulations, the police were given the power to detain anyone suspected of having Covid-19.

However, on 26 March, 2020 these regulations were replaced with the Health Protection (Corona virus Restrictions) (England) Regulation 20205. The Regulations, contain Rules, relating to movement, restrictions and business closures ${ }^{6}$.

Furthermore, there is the Regulation 8 (2) which empowers the police to issue a prohibition notice. In this case, a constable or a police community support officer (PCSO) may issue a prohibition notice requiring compliance to a person contravening these restrictions including a notice for closure of business ${ }^{7}$.

Other Regulations include, but not limited to, power to direct or remove a person to their place of living ${ }^{8}$. Also is power with respect to gatherings ${ }^{9}$. Power to issue a fixed penalty notice ${ }^{10}$. In this case, a constable or a (PCSO) may issue a fixed penalty notice to any individual over 18 years old who they reasonably believe has committed an offence. The fine for a first offence is E60 (reduced to E30 if paid within 14 days) and E120 for a second. The fine doubles for each subsequent offence up to a maximum of E 960. Prosecution is also an option, payment to a local authority under a fixed penalty notice would discharge any liability to conviction and no proceedings may be commenced for the offence for 28 days following the date of the notice.

Another regulation is the Corona virus Act $2020^{11}$. This was followed by the power Relating to potentially infectious persons (schedule 21 of the Act). This came into force as a result of the declaration made by the Secretary of State on the 10 February, 2020. The incidence of transmission of Corona virus constituted a

\footnotetext{
${ }^{1}$ WHO Director-General's opening remarks at the media briefing on Covid-19, April 13, 2020. Available at WWW.who.int. accessed on 2/7/2020. During the Covid-19 pandemic, human rights violations including censorship, discrimination, arbitrary detention and xenophobia were reported from different parts of the world.

25 February,2020 the human rights violations hinder rather than facilitate responses to public health emergencies and undercut the efficiency. See https://www.amnesty.org.

${ }^{3}$ The Guardian Newspaper 23 March, 2020 culled from https://www.theguardian.com. Last accessed on 2/7/2020.

${ }^{4}$ Ibid.

${ }^{5}$ Section 45 R of the Public Health (Control of Disease) Act, 1984 which is referred to as Regulation 2020.

${ }^{6}$ The Prime Minister Bori Johnson announced this on 23 March, 2020. The Regulations allow the police to take action necessary to enforce the new restrictions. This restriction apply during the "emergency period" which started on 26 March, 2020, the date the Regulations came into force in England, Wales and Scotland. It will continue until terminated by a direction of the secretary of state. See https://www.sidkey.com last accessed on 2/7/2020.

${ }^{7}$ Regulation 8 (2).

${ }^{8}$ Regulation 8 (3) - (8), if a police officer considers that an individual is outside of their place of living without a reasonable excuse, the officer may direct that person to return to the place where they are living, unreasonable force where if necessary. ${ }^{9}$ Regulation 8 (9).

${ }^{10}$ Regulation 10.

${ }^{11}$ The government announced on 8 March, 2020, that it intended to introduce the Corona virus Bill 2019- 2021. The bill was laid before parliament on 19 March, 2020 and received Royal Assent on 26 March, 2020. It allows the government to impose restrictions or prohibit events or gatherings and strengthens police powers of detention.
} 
serious and imminent threat to public health. Measures outlined in the Health Protection (Corona virus) Regulations 2020 (now replaced with the Regulations and the Act) were deemed an effective means of delaying and preventing further transmission. Under this regulation, a constable possesses the power to direct or remove a person to a place for screening and assessment and, Power to enforce a quarantine ${ }^{1}$.Furthermore, there is also powers relating to events and gathering ${ }^{2}$. All these regulations were passed by Parliament and not Executive order as in the case of Nigeria.

\section{Human Rights Implication of the Emergency Laws.}

In Britain, the human rights implication are manifold. In the first place, measures introduced by the government raise a number of concerns with respect to their effect on human rights under the Europeans Convention on Human Rights, (The Convention) and the Human Rights Act 1998 (HRA). It is unlawful for public authorities to act in a way that is incompatible with the Convention ${ }^{3}$.

Most Government's responses to the Corona virus crisis have included a strict curtailment of the right to freedom of movement. Some EU member states have imposed these, and further limitations as part of an officially declared "State of Emergency". This special measure provides government to impose extraordinary legal measures. EU communities are not free to shape their emergency measures as they wish. EU treaties and human rights instruments such as the European Convention on Human Rights (ECHR), OSCE commitments and the UN human rights treaty system continue to apply even during crisis. These obligations guarantee human rights and elements of the rule of law during emergencies, such as the prohibition of torture, inhuman or cruel treatment and punishment. Other rights and freedom may be limited, but their essential core must remain intact. While one can expect limits in the ability to administer justice and see non-essential court cases delayed due to shutdowns, elements of the right to fair-trial, such as the right to challenge an arrest before an independent court must be preserved. Moreover, some regional and international instruments, such as the ECHR, feature a mechanism for countries to notify the relevant organization that they are suspending some elements of the legal instrument when facing an exceptional, clearly, identifiable threat by exacting temporary extraordinary measures. National security and public health are primarily under the responsibility of each EU country, which means that each state has its own regulations to deal with large scale crisis or state of emergency.

Also, police powers to isolate potentially infectious persons and enforce movement restrictions may interfere with the right of liberty as protected by Article 5 of the Convention. It also interferes with the rights to private and family life under Article 8 of the Convention. Restrictions on gatherings potentially pose a threat to the rights to freedom of expression and assembly and association ${ }^{4}$.

Finally in Britain, any restrictions of these rights must be legal, pursue a legitimate aim and be necessary in a democratic society, that is, proportionate.

It must be noted that, generally, the International Covenant on Economic, Social and Cultural Rights does not include a provision on derogation. States obligations associated with the case content of the rights to food, health, housing, social protection, water and sanitation, education and an adequate standard of living remain in effect even during situations of emergency. The European Convention on Human Rights which protects the right to life, the freedom of assembly and freedom of expressions among others are in place during emergency.

A state of emergency means that the fundamental human rights enshrined in Chapter 4 of the 1999 Constitution of Nigeria that protects basic dignity and freedom no longer apply. The government now has the right to make regulations and take such measures as appear to be necessary and expedient without due regard to constitutional safe guards or judicial oversight. These pose grave threats to human rights. The governments have traditionally hidden behind emergency powers and regulation to perpetuate egregious human rights violations, especially against dissenting voices, thereby degenerating into dictatorial abusive fashion. Article 4 of the ICCPR allows states to make derogations from their international human rights obligations during such emergency like, Covid-19 pandemic, if such derogation are proportional and strictly necessary. The clause which

\footnotetext{
${ }^{1}$ In this regard where a person has a confirmed case of Covid-19, or if the results of such tests are inconclusive, a public health officer may impose a 14 days quarantine, which may be extended for a further 14 days. A constable has the power to enforce the requirement by removing the person to and keeping that person at the place of quarantine. If the person absconds, a constable may take him into custody and return the person to the place of quarantine. Even under Ancillary powers the police may use reasonable force and enter any place in exercising the powers given by the Act.

${ }^{2}$ See clause 52 and schedule 22 of the Corona virus Act 2020. In this case the police has powers to enforce compliance with any such direction including the power to enter premises and use reasonable force if necessary.

${ }^{3}$ Section 6 of the Human Rights Act 1998.

${ }^{4}$ See Articles 10 and 11 of the Convention on Human Rights.
} 
is conditional, does not give the uniformed army, like what happened in the Warri, Delta State, to degenerate to shooting armless citizens on the Street. In other climes like America and Britain, there was no such report of draconia enforcement. The police are in charge and to some extent, they are civil.

\section{Conclusion and Recommendation}

The situation presented by the Covid-19 pandemic requires many countries worldwide to take extraordinary measures to protect the health and wellbeing of the population. Even in a public emergency, these steps need to be based on the rule of law.

Emergency powers should be used within the parameters provided by the ground norm of the countries and within international human rights law, particularly the International Covenant on Civil and Political Rights (ICCPR) which acknowledges that states may need additional powers to address exceptional situations. Such powers should be time bound and only exercised on a temporary basis with the aim to restore a state of normalcy as soon as possible.

Also, without a state declaring state of emergency, states can adopt exceptional measures to protect public health that may restrict certain human rights. These restrictions must meet the requirements of legality, necessity and proportionality. The suspension or derogation of certain civil and political rights is only allowed under specific situation of emergency that threaten the life of the citizenry of a nation. However, some safe guards must be put in place including the respect of some fundamental rights that cannot be suspended under any circumstances.

The situation in Nigeria during emergency relating to Covid-19 pandemic is very worrisome. Most regulations were made without reference to the National Assembly or Parliament as they were not law per se. Even the President under Executive order No.10 did not make reference to the National Assembly for an Executive bill. Inspite of this, the police, Army and other security agencies continued to trample and violate the rights of the public. The situation in Warri, Delta State as reported by the various media, is very gory where army relied on the lockdowns to open fire arms that killed Pessu. This does not happen in Britain and America.

In Britain for instance, the bill was sent to the Royal for assent which means the parliament was still working. It is hereby recommended that this situation should be adopted in Nigeria.

\section{Recommendation}

It is true that some rights such as freedom of movement, freedom of expression or freedom of peaceful assembly may be subject to restriction for public health reasons, even in the absence of state of emergency. However, these restrictions must meet the following requirements as they affect the human rights.

In the first place, the restrictions must be founded on the principle of legality. This means that the restriction must be provided by law. The limitation must be contained in a national law of general application, which is in force at the time the limitation is applied. The law must not be arbitrary, unreasonable, and it must be clear and accessible to the public.

Also, the restriction must be necessary for the protection of one of the permissible grounds in the ICCPR which includes Public Health and must respond to a pressing social need.

Furthermore, it must be founded on proportionality. The restriction must be proportionate to the interest at stake ie. It must be proportionate to achieve protective function.

States should take measures to prevent human rights violations and abuses associated with the state of emergency perpetrated by state and non state actors. Allegations of such violations and abuses should be effectively and promptly investigated with a view to putting an end to the violations or abuses, bringing perpetrators to justice and providing victims with protection and effective remedies.

The principle of legality and the rule of law require that fundamental requirement of fair trial must be respected during emergency. Only a court of law may try and convict a person for a criminal offence not the case that happened in Rivers State, Nigeria. Emergency declarations based on the Covid-19 outbreak should not be used as basis to target individuals or groups, including minorities.

Even in case of Covid-19 pandemic law, enforcement operations carried out should comply with relevant municipal or domestic laws and standards and international norms, including code of conduct for Law Enforcement Official, Basic Principles, on the use of Force and Fire arms by Law Enforcement Officials and the U.N, Human Rights Guidance on the use of less lethal weapons by Law Enforcement.

As a general rule, the military should not conduct policing functions during emergency as Covid-19 lockdowns and restrictions. 